\title{
Wildfire yields a distinct turnover of the beetle community in a semi-natural pine forest in northern Sweden
}

\author{
Emelie Fredriksson ${ }^{1 *}$ D, Roger Mugerwa Pettersson ${ }^{1}$, Jörgen Naalisvaara ${ }^{2}$ and Therese Löfroth ${ }^{1}$
}

\begin{abstract}
Background: Fires have been an important natural disturbance and pervasive evolutionary force in the boreal biome. Yet, fire suppression has made forest fires rare in the managed landscapes in Fennoscandia, causing significant habitat loss for saproxylic species such as polypores and insects. To better understand how the beetle community changes (species turnover) after a wildfire in a landscape with intense fire suppression, we monitored beetles with flight intercept traps the first 3 years as well as 12 years after a large wildfire in a national park in northern Sweden (a control/unburnt area was set up for the last year of sampling).

Results: Species composition changed significantly among all studied years with a continuous turnover of species following the wildfire. The indicator species analysis showed that year 1 post-fire was mostly associated with cambium consumers and also the pyrophilous species Batrisodes hubenthali. Year 2 was the most abundant and species-rich year, with Tomicus piniperda as the most important indicator species. The indicator species year 3 were mostly secondary successional species, fungivores, and predators and were characterized by lower species diversity. Year 12 had higher diversity compared with year 3 but lower species richness and abundance. A control area was established during year 12 post-fire, and our analyses showed that the control area and burned area differed in species composition suggesting that the beetle community needs longer than 12 years to recover even after a lowintensive ground fire.

Conclusion: The wildfire area hosted several red-listed and fire-dependent species suggesting that after a century of landscape-level fire suppression in a semi-natural area, the reintroduction of fire benefits rare and pyrophilous species and still impacts species composition after 12 years. This study implies that fire has long-lasting effects on high latitudes and that prescribed burning has the potential to benefit biodiversity over decades in these landscapes while also highlighting the value of considering the whole species community and not only monitoring abundance and richness to assess biodiversity after management actions.
\end{abstract}

Keywords: Assemblage, Boreal, Coleoptera, Species composition, Conservation, Disturbance, Diversity, Fire suppression, Insects, Protected area, Saproxylic

\footnotetext{
* Correspondence: emelie.fredriksson@slu.se

'Wildlife, Fish, and Environmental studies, Swedish University of Agricultural

Sciences, Skogsmarksgränd 17, 90183 Umeå, Sweden

Full list of author information is available at the end of the article
}

\section{Springer Open}

(c) The Author(s). 2020 Open Access This article is licensed under a Creative Commons Attribution 4.0 International License, which permits use, sharing, adaptation, distribution and reproduction in any medium or format, as long as you give appropriate credit to the original author(s) and the source, provide a link to the Creative Commons licence, and indicate if changes were made. The images or other third party material in this article are included in the article's Creative Commons licence, unless indicated otherwise in a credit line to the material. If material is not included in the article's Creative Commons licence and your intended use is not permitted by statutory regulation or exceeds the permitted use, you will need to obtain permission directly from the copyright holder. To view a copy of this licence, visit http://creativecommons.org/licenses/by/4.0/. 


\section{Background}

Habitat loss and the subsequent loss of structures and processes are one of the main drivers of biodiversity decline globally (Sánchez-Bayo and Wyckhuys 2019; Grooten and Almond 2018; Angelstam et al. 2013). To reverse this trend, it is crucial to understand the natural processes that maintain biodiversity and how it is affected by current management (Felton et al. 2020; Svensson et al. 2019; Cardinale et al. 2012). In forested biomes, two structures of high importance for biodiversity are dead wood and large mature trees (Paillet et al. 2010; Humphrey et al. 2004; Grove 2002; Nilsson et al. 2002; Stokland 2001; Martikainen et al. 2000; McMinn and Crossley 1996). In Fennoscandia, four to five thousand species are dependent on dead wood and the amount of dead wood has decreased by $90-98 \%$ in the last 200 years (Siitonen 2001), with negative effects on many taxa (Penttilä et al. 2004; Grove 2002). With such a large reduction of habitat Siitonen (2001) estimate, a minimum 22-32\% decline in saproxylic species in Fennoscandia. For example, a large number of beetle species are directly or indirectly linked with dead wood amount, quality, and/or diversity (Stokland et al. 2012; Grove 2002) and the volume and quality of dead wood vary in time and space depending on the disturbance regime (Bishop et al. 2009) and many species have thus developed adaptations to disturbances such as fire (Wikars 1997).

Before large-scale anthropogenic impact in the boreal forest, the most important stand-replacing disturbances were fire, wind, and insect outbreaks, and small-scale disturbances were common (Engelmark 1999; Esseen et al. 1992). Large areas of the boreal forest had long continuity and high amount of coarse woody debris (Esseen et al. 1992). During the last 100-150 years, there has been an intense use of the boreal forest in Fennoscandia for timber and pulp production, which has transformed the landscape from the natural old-growth forest with natural disturbance regimes towards managed conifer plantations (Östlund et al. 1997) and clearcutting has to a large extent replaced fire as the main stand-replacing disturbance (Gauthier 2009; Bergeron et al. 2002). From the mid-20th century, the main method for timber harvest and regeneration is clearcutting and soil scarification followed by conifer plantation. This method partly mimics a natural largescale disturbance which creates open areas with increased sun exposure that favors some light-demanding species (Jonsell et al. 1998). However, since the trees are removed, the development of dead wood is prevented to a large extent, which removes essential elements for wood dependent species. To reduce the obvious negative effects of clear-felling on biodiversity several measures, including dead wood creation and green tree retention, have been implemented in Swedish forestry from the early 1990s (Anonomous 2015; Johansson et al. 2013; Gustafsson and Perhans 2010; Wikars et al. 2005).
Prescribed burning is also demanded in the FSCcertification and performed on approximately $5 \%$ of the clear-cut area every year (Forest Stewardship Council Sweden 2010).

The interval between fire events has declined considerably due to modern fire suppression (Wallenius et al. 2007; Zackrisson 1977) with only $0.01 \%$ of the productive forest area burn every year in Sweden, compared to approximately $1 \%$ with a "natural" fire regime (Granström 2001). Fire suppression is having profound negative effects on numerous species in the boreal forest (Hekkala et al. 2014; Johansson et al. 2007; Toivanen and Kotiaho 2007; Vanha-Majamaa et al. 2007; Hyvärinen et al. 2006; Saint-Germain et al. 2004; Wikars 2001). In addition, the degradation that decreases the quality of the unburnt habitat in the surrounding landscape also contributes to the decline in pyrophilous species (Kouki et al. 2012; Saint-Germain et al. 2008). The remaining semi-natural areas can be central source habitats for biodiversity in the larger ecological landscape (Hansen and DeFries 2007) and also include natural disturbances or have the potential for conservation actions, such as prescribed burning. Prescribed burning can create a highquality habitat with larger amounts of dead wood and at the same time maintaining elements specific to fire disturbance (Wallenius et al. 2007).

Natural processes such as disturbance and succession are drivers of temporal species turnover (Jackson and Sax 2010). Here we define the term turnover as the temporal changes in abundance and occurrences of both individual species and functional groups. There are several factors that drive turnover. Chesson and Huntly (1997) argued that biological differences between species make it possible for them to inhabit different ecological niches and by doing so utilize different successional stages, thus creating a temporal shift in species composition. Life history and strategies come with trade-offs that make some species more adapted to early successional stages, commonly species with long dispersal capabilities that can take advantage of the low competition and high resource availability after a disturbance event such as a fire, while other species (such as predators or secondary saproxylic species) either depend on the early successional species or have a different ecological strategy that is more favored in the later successional stages with higher competition and sparser resources. Turnover in this sense is driven by local extinction and colonization (White 2004). The functional groups provide a framework to follow these temporal changes after a disturbance event to develop our understanding of its importance to species distribution and occurrence.

The aim of this study is to assess the turnover in the beetle community composition after a unique wildfire event in a semi-natural boreal forest in the Muddus 
National Park in northern Sweden. Fire generally impacts beetle composition favoring early successional species at the expense of climax species (Hekkala et al. 2014; Johansson et al. 2011), and the effects might last for decades (Heikkala et al. 2016). We predicted that the beetle composition would change among the years and that this turnover shifts from pyrophilous species and early successional species within functional groups such as cambivores, towards later successional species such as fungivores the following years after the wildfire. We also predicted that rare pyrophilous species and red-listed species would occur all the monitored post-fire years but with a declining trend in abundance and richness and that a difference in the beetle composition, richness, and abundance would still be prevalent 12 years after the fire (Koivula and Vanha-Majamaa 2020).

\section{Materials and methods}

\section{Study area}

The study area is located in northern Sweden, within the northern boreal zone (Ahti et al. 1968), where a wildfire created a 300 ha burnt area during the summer of 2006 (Engelmark 2013). The fire started the 12th of August as a result of a lightning strike. The ground conditions were very dry, and the fire was active during 6 days before it was put out. The year of the wildfire as well as the sampled years' average air temperature between May and September and the total precipitation varied within normal ranges; however, the first year after the wildfire had the most precipitation and the third year had the least amount (Table 1).

The area is dominated by an old-growth pine forest which mostly survived due to the fire's low intensity (Fig. 1) that did not directly kill the trees but reduced the depth of the humus layer (Engelmark 2013). The burnt area forms part of the Muddus (or Muttos) National Park (between $66^{\circ} 45^{\prime} \mathrm{N}, 20^{\circ} 15^{\prime} \mathrm{E}$, and $65^{\circ} 5^{\prime} \mathrm{N}$, $20^{\circ} 15^{\prime} \mathrm{E}$ ), the largest continuous semi-natural forest area below the mountain range in Sweden. The Muddus National Park consists of forested land and mires in about equal parts. The northern parts are mostly

Table 1 Temperature (average of daily temperature \pm standard deviation) and total precipitation during the sampling months (including May to September) from a public measurement station in Jokkmokk, about $20 \mathrm{~km}$ from the study area (SMHI 2018)

\begin{tabular}{lll}
\hline Year & Mean temperature $\left({ }^{\circ} \mathrm{C}\right)$ & Sum precipitation $(\mathrm{mm})$ \\
\hline 2006 & $12.1 \pm 5.3$ & 272 \\
2007 & $10.4 \pm 5.3$ & 425 \\
2008 & $9.9 \pm 4.9$ & 300 \\
2009 & $12.1 \pm 4.3$ & 186 \\
2018 & $12.0 \pm 5.1$ & 257 \\
\hline
\end{tabular}

covered with mires and Norway spruce (Picea abies, (L.) $\mathrm{H}$. Karst) while the southern parts of the park (where the study area is located) are dominated by Scots pine (Pinus sylvestris L.) forest (Engelmark 2013). Birch (Betula pubescens Ehrh. and Betula pendula Roth) occurs over the entire area.

The fire history in the Muddus is well recorded with the last dated fire before the wildfire in 2006 in 1946 (for more details see Niklasson and Granström (2000)). The area has likely been less impacted by fire suppression than the surrounding landscapes due to its arduous terrain and no roads within the park; however, the frequency of fires has decreased during the last century (Engelmark 1984). A larger extent of the recorded fires has been in the southern parts with a drier pine forest compared with the northern parts with a mosaic of mires (Engelmark 1984). Muddus was protected in 1942 and has been affected relatively little by human activities. The anthropogenic disturbances that have occurred are haymaking at the borders of the park's mires, extensive reindeer grazing, and selective cutting of large trees in the southern parts during the timber-floating period of the late 19th century.

\section{Sampling design and insect collection}

Insects were sampled from the burned area for three consecutive years after the fire (2007-2009) by the County Administration Board of Norrbotten. For each of the years, ten flight intercept traps (model Polish IBL2), in the form of a triangular semi-transparent plastic intercept of $\sim 0.35$ $\mathrm{m}^{2}$, were placed out along a transect through the burnt area in permanent positions during all 3 years (Fig. 1). The distance between the traps ranged between 140 and $300 \mathrm{~m}$, and the total length of the transect was $1.6 \mathrm{~km}$ on the burned area. Twelve years after the fire (2018), a new sampling was done where we also established a control area. We used the same locations for the traps in the burnt area during 2018 as the years 2007-2009. The control area was located adjacent to the burn to the west and had a transect of $1.9 \mathrm{~km}$ with ten traps placed $150-300 \mathrm{~m}$ apart (Fig. 1). The traps were suspended between two trees using ropes. The traps had a water removing the funnel and a collecting bottle of $600 \mathrm{ml}$ that was filled to a third with propylene glycol mixed with water (50/50) and a small amount of detergent (for more details see Stenbacka et al. (2010)). The traps were in place from late May or the beginning of June until late August or early September with the total sampling time among the years not differing more than a couple of weeks. The differences in sampling start and end are considered to not be an issue since swarming times occur late in the season this far north (see detailed flying times for Scolytinae in Hedqvist (1965), Bakke (1968), and Lekander et al. (1977)). The beetles were counted and identified to species level by experts. Acrotrichis spp. was removed from 


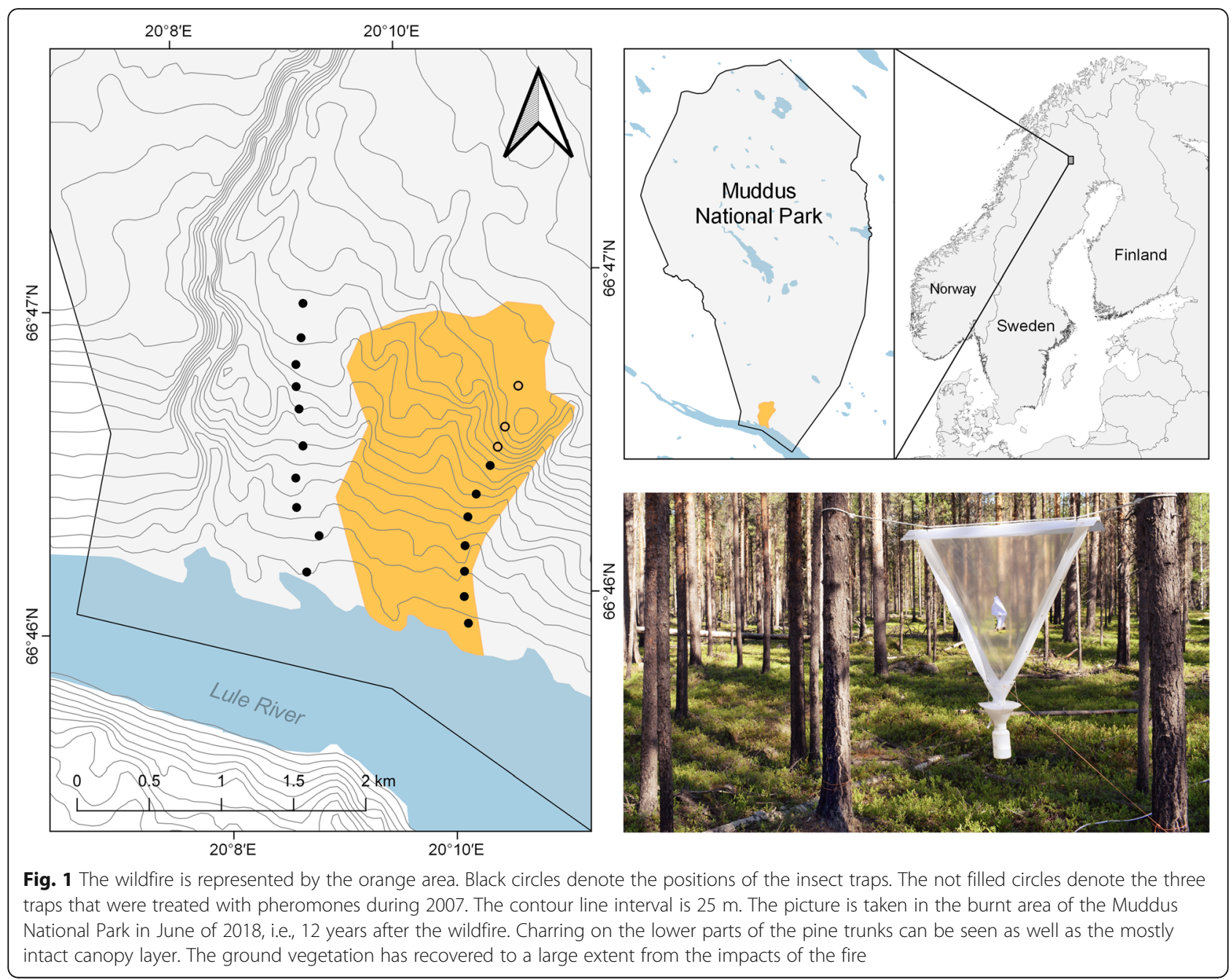

the data set because they were not determined and counted all years. The beetles were divided into groups; saproxylic (facultative and obligatory) and non-saproxylic (Stokland et al. 2012; Speight 1989), functional groups based on nutritional preferences (established by Koch (1992); Koch (1989a); Koch (1989b), Lundberg, S pers. comm. and personal experience), red-list status (Westling 2015), and pyrophilous (fire-dependent and strongly fire favored by Wikars (2006), from here referred to as pyrophilous (class III + II)). Taxonomy and nomenclature of the beetles follow Dyntaxa (Liljeblad 2020). Note that some species are classified to more than one functional group and can, therefore, be part of more than one analysis.

\section{Statistical analyses}

We used trap-specific differences inside the burned site to compare species composition between the years. All the statistical analyses were performed using the statistical software R (R-Core-Team 2015). During year 1 post-fire, three of the traps had been treated with pheromones and were therefore excluded from all analyses.
Differences in abundance and species richness among years were assessed using a negative binomial generalized linear mixed model (overdispersed count data), with the traps as a random factor (function "glmer.nb" in the "MASS" package by Ripley et al. (2013)) and among year comparisons with Tukey's test (function "glht" in the "multicomp" package by Hothorn et al. (2008)). Diversity indices (Shannon and Simpson) were calculated using the "vegan" package, function "diversity," and differences among years were tested with Kruskal-Wallis test followed by Wilcox test for pair-wise comparisons. Indicator species analysis was performed using with the function "multipatt" from the "indicspecies" package (De Cáceres and Legendre 2009). The analysis compares the relationship between species occurrence and/or abundance and sites, in this case, "sites" are the years since wildfire (plus control year 12), in total five different sites. As a measure of a species indicator value, the analysis uses an A-index and a B-index. A-index refers to "specificity", i.e., to the relative exclusivity of the species to that year ( $1=$ only found that year), and the B-index 
refers to "fidelity," i.e. how often the species occurs in the samples within that year $(1=$ found in all samples from that year). The indicator species index combines the $\mathrm{A}$ and $\mathrm{B}$ indices. To compare species composition among the years after the wildfire, we used twodimensional non-metric multidimensional scaling (NMDS, function "metaMDS"), based on Bray-Curtis dissimilarities. To test for significant differences among the years, we used PERMANOVA (function "adonis" from the package "vegan" (Oksanen et al. 2015)). PERMANOVA has been shown to be a powerful analysis for analyzing changes in communities over time, especially for communities with large numbers of species (Irvine et al. 2011). To rule out the possibility that the significance from the PERMANOVA analysis stems from differences in dispersion among the samples rather than from an actual difference between years, we ran a permutation test which was non-significant for all groups except the cambivores (Table S1).

\section{Results}

In total, we caught 11156 individuals of 452 different species, of which 352 species were saproxylic. The most abundant functional group was fungivores with 5859 individuals from 157 different species (see full species list, Table S3).

\section{Changes in species composition}

We found significant changes in the beetle composition among all sampled years after the wildfire and also a difference between the unburnt control and burnt area year 12 (Fig. 2). The pattern is the same and also significant

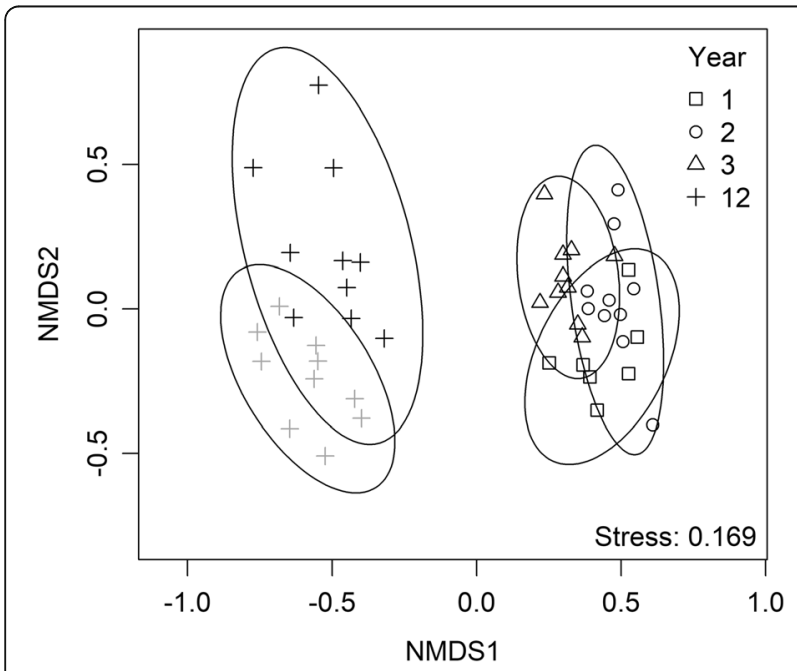

Fig. 2 Two-dimension visualization of the NMDS ordination for the beetle composition of all the species among the years. Each symbol represents the species composition in one trap. The square symbol denotes year 1 post-fire, circle year 2, triangle year 3, and the additions sign year 12. Black points are burned areas while light gray is a non-burnt control. The polygon was drawn based on the standard deviation within each year when comparing each nutritional group one by one and when repeating the analysis with only presence data (results not shown).

Indicator species analysis (see Table S2) showed that year 1 after the fire had 23 significant indicator species, 40 species year 2, 14 species year 3,10 species year 12 , and 9 species at the control area year 12. The indicator species of year 1 was a mix of cambivores, fungivores, and predators while the later years were dominated by fungivores and predators. When excluding the singletons and doubletons, the general proportions of unique species among the years did not change. All indicator species were of red-list category "least concern" (LC), except for Ips acuminatus (Gyllenhal, 1827) that is classified as "near threatened" (NT) and Batrisodes hubenthali (Reitter, 1913) that is considered "vulnerable" (VU) which were indicators during year 1 while Enicmus planipennis (Strand, 1940) (NT) was found year 3. Two pyrophilous species were significant indicators for year 1, Hylobius abietis (Linnaeus, 1758) and Henoticus serratus (Gyllenhal, 1808). Year 3 had one indicator species that was pyrophilous, Cryptophagus corticinus (Thomson, 1863). The majority of the indicator species were saproxylic (80 of 96 species).

\section{Species diversity, abundance, and richness}

The overall species diversity index shows a decreased diversity year 3 (Shannon $P$ value: 0.0052 , Simpson $P$ value: 0.0259 between years 2 and 3 ) and showed a statistically significant increase year 12 when looking at Simpson but not Shannon index (Fig. 3). There was no difference in diversity between the burned and the control area year 12 .

Saproxylic beetles constituted the majority of the individuals and species caught and they, as well as most of the other functional groups, display a peak in abundance and species richness years 2 or 3 post-fire (Fig. 4). Pyrophilous species and red-listed abundance indicate a slight decreasing trend from year 1 towards year 12. The abundance and species richness are similar in the burned area and the control year 12 for all functional groups.

\section{Red-listed and pyrophilous species}

The total number of red-listed species caught was 33 (18 species year 1, 14 species year 2,13 species year 3 , 8 species year 12, and 4 in the control area year 12 after the fire). The total number of pyrophilous species caught among all years was 18 (12 species year 1, 9 species year 2,10 species year 3,7 species year 12 , and 4 species year 12 in the control area). The majority of these species were only caught once or twice per year and all were saproxylic. A summary of species that are both red-listed and at least fire favored (I) can be found in Table 2 . None of these species were caught all the years after the 


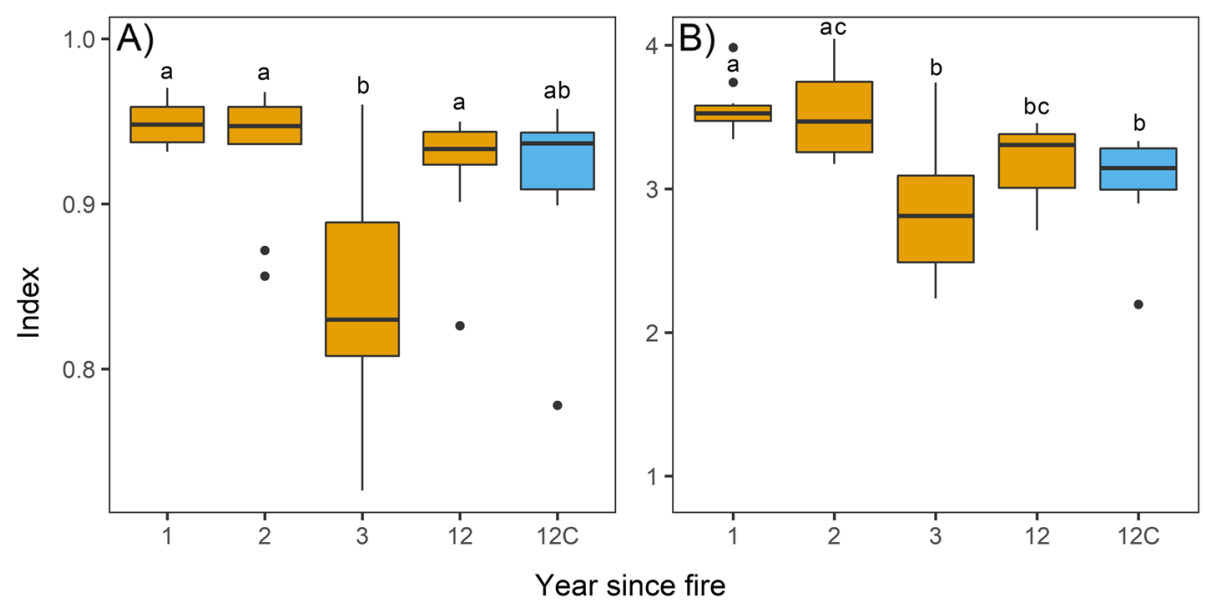

Fig. 3 Diversity index comparing the years since the wildfire of all species (a Simpson index, b Shannon index). Letters indicate significant differences ( $P$ value $<0.05$, Kruskal-Wallis test and a pairwise Mann-Whitney $U$ test, $P$ values adjusted). Note the different scales in the plots and the $C$ on the $x$-axis referring to the control area year 12
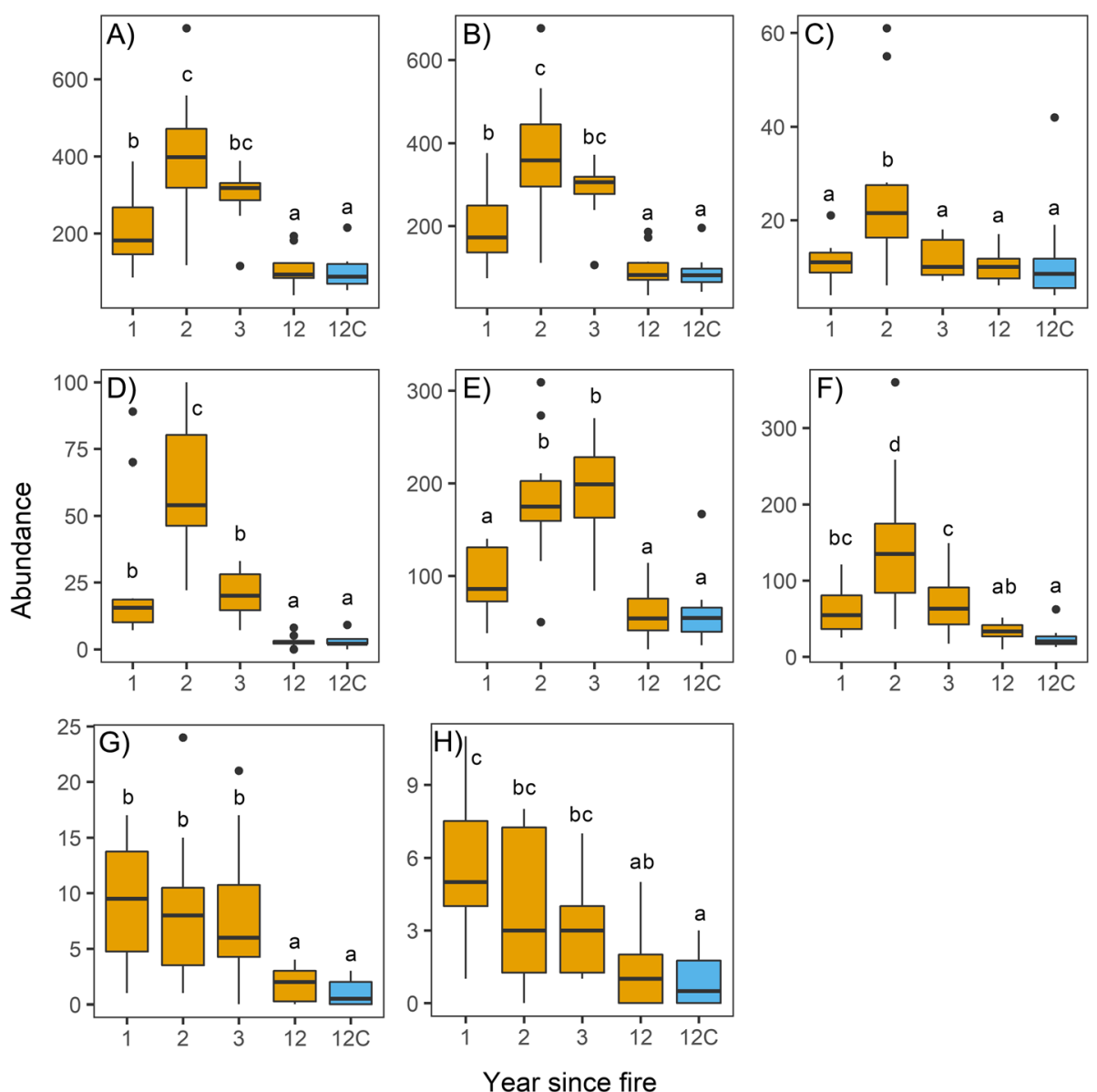

Fig. 4 Boxplot of the abundance of caught beetles' in different functional groups after the wildfire (a all individuals, b saproxylic, c nonsaproxylic, $\mathbf{d}$ cambivore, e fungivore, $\mathbf{f}$ predator, $\mathbf{g}$ pyrophilous, $\mathbf{h}$ red-listed). Letters indicate significant differences $(P$ value $<0.05$, negative binomial GLMM and Tukey's test). Note the different scales in the plots and the $C$ on the $x$-axis referring to the control area year 12 
Table 2 Species that are either I = fire favored, II = strongly fire favored, and III = fire-dependent and also has a red-list category of at least NT are presented in the table (NT: near threatened, VU: vulnerable, EN: endangered). The different nutritional preferences of the species are represented with C for cambivore, W for wood-boring, F for fungivore, P for predator, D for detrivore and '?' before the letter indicating the functional group expresses uncertainty in that classification

\begin{tabular}{|c|c|c|c|c|c|c|c|c|}
\hline \multirow[b]{2}{*}{ Species } & \multirow[b]{2}{*}{ Nutrition } & \multirow[b]{2}{*}{ Fire category } & \multirow[b]{2}{*}{ Red-list category } & \multicolumn{5}{|c|}{ Year since fire } \\
\hline & & & & 1 & 2 & 3 & 12 & $12 \mathrm{C}$ \\
\hline Acmaeops marginatus & $C, D$ & $\|$ & EN & 0 & 0 & 1 & 1 & 0 \\
\hline Acmaeops septentrionis & $C, W$ & $\|$ & NT & 0 & 0 & 2 & 1 & 1 \\
\hline Atomaria affinis & $? F, ? D, P$ & 1 & NT & 0 & 0 & 0 & 4 & 5 \\
\hline Batrisodes hubenthali & $? \mathrm{P}$ & 1 & VU & 11 & 1 & 0 & 3 & 2 \\
\hline Carphoborus cholodkovskyi & C & I & NT & 3 & 0 & 0 & 0 & 0 \\
\hline Corticaria polypori & $\mathrm{F}$ & 1 & NT & 0 & 5 & 3 & 0 & 0 \\
\hline Denticollis borealis & $P, W$ & $\|$ & NT & 2 & 0 & 0 & 0 & 0 \\
\hline Hadrobregmus confusus & W & 1 & NT & 2 & 1 & 0 & 0 & 0 \\
\hline Ips acuminatus & $C, F$ & । & NT & 13 & 0 & 0 & 0 & 0 \\
\hline Laemophloeus muticus & $F, W, P$ & III & $\mathrm{VU}$ & 3 & 5 & 2 & 0 & 0 \\
\hline Melandrya dubia & $? \mathrm{~F}$ & । & $\mathrm{VU}$ & 2 & 0 & 0 & 0 & 0 \\
\hline Olisthaerus megacephalus & $? \mathrm{P}$ & I & NT & 2 & 0 & 0 & 0 & 0 \\
\hline Olisthaerus substriatus & P & 1 & NT & 0 & 0 & 1 & 0 & 0 \\
\hline Stagetus borealis & $F, W$ & I & NT & 0 & 0 & 0 & 1 & 0 \\
\hline Zilora ferruginea & $\mathrm{F}$ & 1 & NT & 1 & 0 & 0 & 0 & 0 \\
\hline Total abundance & & & & 33 & 12 & 9 & 10 & 7 \\
\hline
\end{tabular}

fire. The endangered and strongly fire favored species Acmaeops marginatus (Fabricius, 1781) was caught year 3 and year 12 post-fire.

The species richness and the abundance decrease with time for both pyrophilous and red-listed beetles but are only significant when comparing year 1 and year 12 (both fire and control, Figs. 4 and 5). Pyrophilous total abundance was highest during the year 1 (year $1=95$ individuals, year $2=87$ individuals, year $3=81$ individuals, year $12=18$ individuals, control year $12=10$ individuals). The number of red-listed individuals had the same declining trend following the abundance of year 1 (year $1=55$ individuals, year $2=38$ individuals, year $3=32$ individuals, year $12=13$ individuals, control year $12=9$ individuals).

\section{Discussion}

\section{Community composition}

We found support for our prediction that there was a turnover in beetle community composition after the wildfire (Fig. 1). This change is reflected in differences in species richness, the abundance of the functional groups and continuously shifting species composition. Since the turnover among the years still exists when looking at only presence/absence data, we can be more certain in our conclusion that an actual turnover of species has taken place and that it is not an artifact of very abundant or rare species. We show that the composition after 12 years differs from an unburned control area suggesting that fire has decadal effects on beetle composition at high latitudes. The study area is the largest semi-natural forest below the mountain range in Sweden in a landscape shaped by fire suppression and heavily managed forests, making this uncommonly large wildfire event important to further our understanding of the long-term effects on the beetle community composition. Note that this is a case study with only one area, which means that the non-difference we found in diversity between the control and burned areas year 12 is on the stand scale, however not excluding that fire most likely causes longterm positive effects on landscape-level species diversity. Most studies detecting effects on pyrophilous insects include at most two sampling years after fire (Johansson et al. 2011; Hyvärinen et al. 2006; Wikars 2002) but see Hekkala et al. (2014) and Heikkala et al. (2016) that also suggest decadal effects. Similar to a study by SaintGermain et al. (2004) that looked at beetle composition 2 years following a large-scale black spruce (Picea mariana (Mill.) Britton, Sterns, \& Poggen b.) forest fire in North America, our results show that time since fire (year) significantly affects the species composition. Not only wildfire but also restoration fire has been shown to promote changes in beetle composition (Hjältén et al. 2017; Hekkala et al. 2014; Boucher et al. 2012; Hyvärinen et al. 2005). One study showed an increased abundance of redlisted and rare saproxylic beetles following burning (Hyvärinen et al. 2005) while Hjältén et al. (2017) showed 

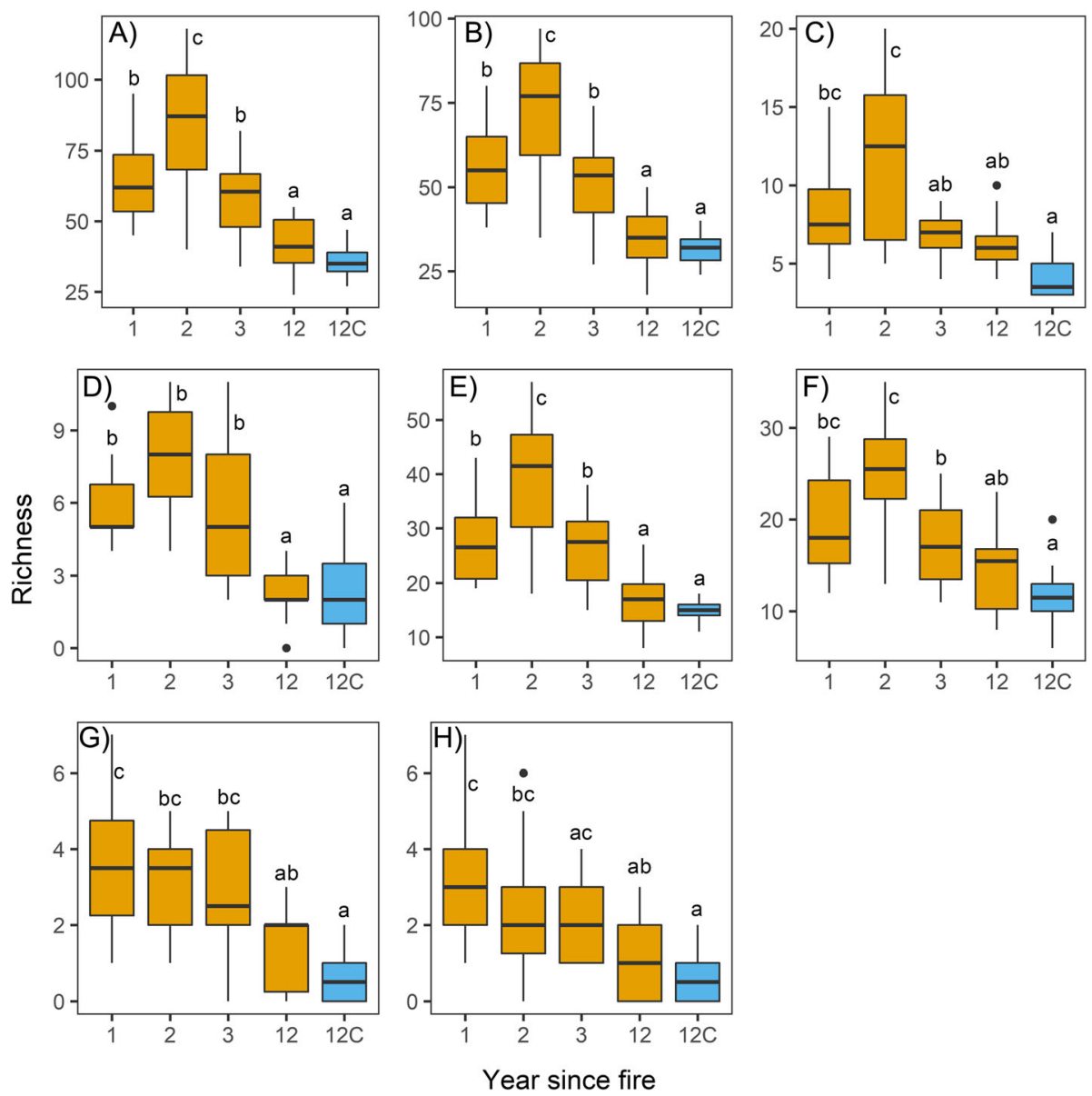

Fig. 5 Boxplot of the species richness of caught beetles' in different functional groups after the wildfire (a all individuals, b saproxylic, $\mathbf{c}$ nonsaproxylic, $\mathbf{d}$ cambivore, e fungivore, $\mathbf{f}$ predator, $\mathbf{g}$ pyrophilous, h red-listed). Letters indicate significant differences $(P$ value $<0.05$, negative binomial GLMM and Tukey's test). Note the different scales in the plots and the $\mathrm{C}$ on the $x$-axis referring to the control area year 12

significant increases in abundance and species richness of beetles the same year of restoration burning. Another study on restoration burning saw a decline of beetles after 5 years following the initial increase after the fire and points out the importance of reoccurrence of fire at the landscape level (Hekkala et al. 2014).

\section{Functional groups}

In accordance with our predictions, our results show that the different functional groups of beetles (i.e., different niche preferences) are affected by the changing conditions after the fire and exhibit a turnover among the years from more early successional species towards latesuccessional groups and more generalist species. The cambivores decline after an initial boost in abundance and species richness, while fungivores have an increase in abundance over the first 3 years but are less abundant again year 12 (Fig. 4). Much of the response year 1 can be attributed to abundant generalist species like Tomicus piniperda (Linnaeus, 1758) that are attracted by the dead and dying trees in a burned area (Byers 1992; Eidmann et al. 1990). The decrease in diversity during year 3 is likely due to the dominance of Rhizophagus fenestralis (Linnaeus, 1758), Cryptophagus lapponicus (Gyllenhal, 1827) and Trypodendron laeve (Eggers, 1939) constituting $42 \%$ of the catch and a likely result from the increase in available food and hatching during that year. Even though the fire was of low intensity and thus caused low tree mortality, there was still an initial and ongoing addition of new coarse woody debris over the years compared with the control area with lesser amounts of dead wood and with different quality (Vahlström 2019). Most of the functional groups presented an increase in species richness and abundance between year 1 and the year 2 after the fire. Several cambivore species that occurred in large abundances were indicators for the year 2 (such as T. piniperda, Hylastes brunneus (Erichson, 1836) and Hylurgops palliates (Gyllenhal, 1813)). The low-intensity fire that occurred relatively late in the summer likely delayed the trees from dying and attracted the cambium 
consumers during year 2 instead of year 1 since they are drawn to fresh dead wood before the cambium is consumed or dries up. However, some species such as $T$. piniperda colonize the wood during year 1 and hatch during year 2, so the large catch year 2 could also be individuals that hatched in spring that year. The cambivores leave as soon as the cambium is consumed which is usually within a few years, this would explain the significantly lower abundance and species richness year 3 and year 12 (Figs. 4 and 5). During year 3 secondary successional species such as predators, fungivores, or saproxylic species that use other parts of the wood than the cambium or the tracks left in the bark by other beetles, followed the primary successional species. These included for example the fungivores C. lapponicus and Atomaria bella (Reitter, 1875). We saw a general trend of low or lowest species richness and abundance for among all functional groups year 12 (Figs. 4 and 5). In the burnt area year 12, there was still a few indicator species favored by fire (I), like the predator Lygistopterus sanguineus (Linnaeus, 1758), but not pyrophilous in the way we define it in this paper, while none of the indicator species in the control area had been fire favored. We found no statistical difference in beetle richness and abundance between control and burned area year 12, which point to the conclusion that the effects from the fire disturbance have ceased.

\section{Pyrophilious and red-listed species}

We expected the study area in the Muddus National Park to host a range of rare and pyrophilous species due to its northern geographical location, semi-natural character, and the presence of natural processes like wildfire during centuries. One example being Quedius lundbergi (Palm, 1973) that is classified as near threatened (NT) and is not known outside of northern Sweden and Finland. Q. lundbergi was caught year 1 and year 3 in this study. Little is known about the ecology of the species, but it is most likely a predator and negatively impacted by clear-cutting since it has only been found in forest retaining old-growth structures (Ljungberg 2005). A more abundant species that also has its distribution in the northern boreal forest is C. lapponicus, found in this study a total of 935 individuals all 3 years after the fire (most abundant year 3 with 820 individuals). C. lapponicus is classified as of least concern (LC) in Sweden and functionally a fungivore. This species and many other classified as fire favored (I) are often positively linked to large amounts of dead wood created by fire disturbance (among other structures such as sun exposure and reduced competition) (Wikars 2006). A new species for Sweden, Euplectus lapponicus, was described in 2010 (Löbl and Mattila 2010), which was after the identification of the specimen from the first 3 years in this study was completed. Most likely some of the individuals identified here during the first three sampled years as Euplectus punctatus (Mulsant, 1861) is, in fact, E. lapponicus. In a survey by the County Administrative Board of Norrbotten during 2015, E. lapponicus, was reported found for the second time globally in an area only about $150 \mathrm{~km}$ from the study area (Högdahl et al. 2017). Not much is known about this new species, but the genus is associated with wood (saproxylic) and many are linked to ants. Dead wood amount as well as diversity in successional stages of the wood are important for red-listed invertebrates (Jonsell et al. 1998), and the long continuity of structures and processes found in the study area are very rare in the managed forest landscape in northern Sweden. Muddus is part of a large, natural, and unfragmented area and therefore potentially providing room for natural disturbances and succession to take place, and in combination with its geographic location, it is most interesting with its possibilities for unique northern species. Some studies have observed initial increases of red-listed and rare species after a fire (Kouki et al. 2012; Hyvärinen et al. 2006; Hyvärinen et al. 2005), but the effects of burning on a longer time scale are not well known; however, see Hekkala et al. (2014) who reported a decline in abundance 5 years post-fire while species compositions still were different from unburnt stands. In this study, we only found a statistical difference between year 1 and the control area year 12 for red-listed or pyrophilous species which could be due to the small sample size. However, the fact that we caught 28 different redlisted species during the first 3 years after fire including the fire-dependent $A$. marginatus that has only been recorded in northern Sweden a few times during the last decades, suggests that these species have persisted in the landscape and that they take advantage of the new habitat created by the wildfire, some even 12 years post-fire. The study area is located near the mountain region in Sweden that has large unmanaged areas with highquality habitat that could be a potential source pool of rare species, as exemplified by the fire in TorneträskSoppero mountainous old-growth forest where several pyrophilous species were found after a fire in 2014 (Högdahl et al. 2017). Also fire events in managed landscapes can have positive impacts on strongly fire-favored species, but here, many species were less abundant than could be expected considering the high productivity of the site (Johansson et al. 2011). Thus, this study supports the view that a semi-natural forest can be an important source pool for species adapted to natural disturbances in boreal forest.

\section{Conclusions}

This study shows that there is a distinct turnover of species after a wildfire in a protected semi-natural area in northern Sweden. Turnover is fast the first 3 years after 
fire, but even 12 years after the disturbance, the beetle species composition on the burned area is different from an unburned control area. Since the data collected for this study comes from a single area affected by a wildfire, the conclusions drawn here are at the stand-level; however, our results are in line with previously cited studies that show positive effects on biodiversity of beetles at a landscape level. The slow recovery of the beetle assemblages after a fire and the occurrence of several rare and threatened species imply that burning can be an efficient method with long-lasting effects for biodiversity at high latitudes. This study also points to the importance of long-term monitoring of beetle community composition after disturbance rather than only abundance or richness if one is to efficiently adapt and allocate prescribed burning and similar disturbance mimicking management actions. To generate proper management guidelines, more research is needed in both wildfire areas and prescribed burnings in both managed and natural landscapes.

\section{Supplementary information}

Supplementary information accompanies this paper at https://doi.org/10. 1186/s13717-020-00246-5.

Additional file 1 Table S1: Output values from the compositional analysis (PERMANOVA) and permutation test (betadisper) when comparing the different functional groups' changes among the years after the wildfire. Note the "**" following the significant value from the permutation test for cambivores. Table S2: Significant species among the years reported in order of highest Index-value from the species indicator analysis. Functional group ( FG, C - cambivore, D - detrivore, F - fungivore, $\mathrm{P}$ - predator, $\mathrm{W}$ - wood-boring) and fire category ( $\mathrm{I}$ = fire favored, $\|$ = strongly fire favored, $\| I=$ fire-dependent) of the significant species with an indicator index of at least 0.6. Red list status indicated in brackets after the Latin name of the species. Star $\left(^{*}\right)$ indicate species that, in contrast to the other species, are non-saproxylic. Question mark (?) indicates uncertainty for that species association to the nutritional group. Table S3. Complete species list. Abundance per year and total. Functional groups: Saproxylic ( $\mathrm{SxO}=$ obligate saproxylic, SxF = facultative saproxylic, $\mathrm{NS}=$ non-saproxylic), Red-list status (LC = least concern, NT = near threatened, $V U$ = endangered, DD/NA/NE = data deficiency/not evaluated), Fire category ( $=$ fire favoured, $\|$ = strongly fire favoured, $\| I=$ fire dependent), Nutrition $=(C=$ cambium consumer, $F=$ fungivore, $W=$ wood-boring, $P$ = predator, $\mathrm{D}=$ detrivore, $\mathrm{H}=$ herbivore, '?' = insufficient knowledge)

\section{Abbreviations}

LC: Least concern; NT: Near threatened; VU: Vulnerable; EN: Endangered; I: Fire favored; II: Strongly fire favored; III: Fire-dependent; C: Cambivore; W: Wood-boring; F: Fungivore; P: Predator; D: Detrivore; SxO: Saproxylic; NS: Non-saproxylic

\section{Acknowledgements}

We would like to thank Stig Lundberg for the identification of the beetles in the first 3 years after the fire. Also, many thanks to Anne-Maarit Hekkala for the comments and discussions about the paper; students Dagmar Bogers, Isak Vahlström, and David Kymmell who helped in the field; and lastly, Sven Lennartsson who did the species identification for year 12 .

\section{Authors' contributions}

RP and JN designed the original study setup and collected the data 2007, 2008, and 2009. EF and TL set up the control area and collected the data 2018. EF performed all the statistical analyses and was the major contributor in writing the manuscript. The authors read and approved the final manuscript

\section{Funding}

County Administrative Board of Norrbotten funded the data collection. This paper is part of a PhD-project funded by "Stiftelsen Oscar och Lili Lamms Minne" and Skogssällskapet (Grants to TL). Open access funding provided by Swedish University of Agricultural Sciences.

\section{Availability of data and materials}

All data generated or analyzed during this study are included in this published article (and its supplementary information files).

Ethics approval and consent to participate

Not applicable.

\section{Consent for publication}

Not applicable.

\section{Competing interests}

The authors declare that they have no competing interests.

\section{Author details}

${ }^{1}$ Wildlife, Fish, and Environmental studies, Swedish University of Agricultural Sciences, Skogsmarksgränd 17, 90183 Umeå, Sweden. ${ }^{2}$ County

Administrative Board of Norrbotten, Stationsgatan 5, 97238 Luleå, Sweden.

Received: 28 February 2020 Accepted: 19 July 2020

Published online: 25 August 2020

\section{References}

Ahti T, Hämet-Ahti L, Jalas J (1968) Vegetation zones and their sections in northwestern Europe. Ann Bot Fenn 5(3):169-211

Angelstam P, Roberge J-M, Axelsson R, Elbakidze M, Bergman K-O, Dahlberg A, Degerman E, Eggers S, Esseen P-A, Hjältén J, Johansson T, Müller J, Paltto H, Snäll T, Soloviy I, Törnblom J (2013) Evidence-based knowledge versus negotiated indicators for assessment of ecological sustainability: the Swedish Forest Stewardship Council standard as a case study. Ambio 42(2):229-240

Anonomous (2015). Forests and Forestry in Sweden. The Royal Swedish Academy of Agriculture and Forestry.

Bakke A (1968) Ecological studies on bark beetles (Coleoptera: Scolytidae) associated with scots pine (Pinus sylvestris L.) in Norway with particular reference to the influence of temperature. Meddelelser fra det Norske Skogsforsoksvesen 21(6):441-602

Bergeron Y, Leduc A, Harvey B, Gauthier S (2002) Natural fire regime: a guide for sustainable management of the Canadian boreal forest. Silva Fennica 36(1):81-95

Bishop DJ, Majka CG, Bondrup-Nielsen S, Peck SB (2009) Deadwood and saproxylic beetle diversity in naturally disturbed and managed spruce forests in Nova Scotia. ZooKeys 22:309-340

Boucher J, Azeria ET, Ibarzabal J, Hébert C (2012) Saproxylic beetles in disturbed boreal forests: temporal dynamics, habitat associations, and community structure. Écoscience 19(4):328-343

Byers JA (1992) Attraction of bark beetles, Tomicus piniperda, Hylurgops palliatus, and Trypodendron domesticum and other insects to short-chain alcohols and monoterpenes. J Chem Ecol 18(12):2385-2402

Cardinale BJ, Duffy JE, Gonzalez A, Hooper DU, Perrings C, Venail P, Narwani A, Mace GM, Tilman D, Wardle DA, Kinzig AP, Daily GC, Loreau M, Grace JB, Larigauderie A, Srivastava DS, Naeem S (2012) Biodiversity loss and its impact on humanity. Nature 486:59-67

Chesson P, Huntly N (1997) The roles of harsh and fluctuating conditions in the dynamics of ecological communities. Am Nat 150(5):519-553

De Cáceres M, Legendre P (2009) Associations between species and groups of sites: indices and statistical inference. Ecology 90(12):3566-3574

Eidmann HH, Klingström A, Axelsson R (1990) Skadegörare i skogen (in Swedish). LTs förlag, Stockholm, Sweden

Engelmark O (1984) Forest fires in the Muddus National Park (northern Sweden) during the past 600 years. Can J Bot 62(5):893-898

Engelmark O (1999) Boreal forest disturbances. Ecosystems of the world, pp. 161186

Engelmark O (2013) Skogsbranden i Muddus nationalpark år 2006 - ekologiska effekter och naturvård 
Esseen P-A, Ehnström B, Ericson L, Sjöberg K (1992) Boreal forests-the focal habitats of Fennoscandia. In: Ecological principles of nature conservation, pp 252-325

Felton A, Löfroth T, Angelstam P, Gustafsson L, Hjältén J, Felton AM, Simonsson P, Dahlberg A, Lindbladh M, Svensson J, Nilsson U, Lodin I, Hedwall PO, Sténs A, Lämås T, Brunet J, Kalén C, Kriström B, Gemmel P, Ranius T (2020) Keeping pace with forestry: multi-scale conservation in a changing production forest matrix. Ambio 49(5):1050-1064

Forest Stewardship Council Sweden (2010) Swedish FSC standard for forest certification including SLIMF indicators. Uppsala, Sweden

Gauthier S (2009) Ecosystem management in the boreal forest: PUQ

Granström A (2001) Fire management for biodiversity in the European boreal Forest. Scand J For Res 16(sup3):62-69

Grooten M, Almond REA (2018) Living planet report 2018: aiming higher

Grove SJ (2002) Saproxylic insect ecology and the sustainable management of forests. Annu Rev Ecol Syst 33(1):1-23

Gustafsson L, Perhans K (2010) Biodiversity conservation in swedish forests: ways forward for a 30-year-old multi-scaled approach. Ambio 39(8):546-554

Hansen AJ, DeFries R (2007) Ecological mechanisms linking protected areas to surrounding lands. Ecol Appl 17(4):974-988

Hedqvist K-J (1965) Studier över för virkesvårdens viktiga barkborrar längs Umeälv (in Swedish). Department of forest products, Stockholm, Sweden

Heikkala O, Martikainen P, Kouki J (2016) Decadal effects of emulating natural disturbances in forest management on saproxylic beetle assemblages. Biol Conserv 194:39-47

Hekkala A-M, Päätalo M-L, Tarvainen O, Tolvanen A (2014) Restoration of young forests in eastern Finland: benefits for saproxylic beetles (Coleoptera). Restor Ecol 22(2):151-159

Hjältén J, Hägglund R, Löfroth T, Roberge JM, Dynesius M, Olsson J (2017) Forest restoration by burning and gap cutting of voluntary set-asides yield distinct immediate effects on saproxylic beetles. Biodivers Conserv 26(7):1623-1640

Högdahl A, Wikars L-O, Hellqvist S, Ramqvist T, Hedgren O, Sandström J (2017) Brandeffekter och insekter efter naturlig skogsbrand i TorneträskSoppero fjällurskog 2014

Hothorn T, Bretz F, Westfall P (2008) Simultaneous inference in general parametric models. Biom J 50(3):346-363

Humphrey JW, Sippola AL, Lempérière G, Dodelin B, Alexander KNA, Butler JE (2004) Deadwood as an indicator of biodiversity in European forests: From theory to operational guidance. EFI Proceedings, Monitoring and Indicators of Forest Biodiversity in Europe - From Ideas to Operationality. European Forest Institute

Hyvärinen E, Kouki J, Martikainen P, Lappalainen H (2005) Short-term effects of controlled burning and green-tree retention on beetle (Coleoptera) assemblages in managed boreal forests. For Ecol Manag 212(1):315-332

Hyvärinen E, Kouki J, Martikainen P (2006) Fire and green-tree retention in conservation of red-listed and rare deadwood-dependent beetles in Finnish boreal forests. Conserv Biol 20(6):1710-1719

Irvine KM, Dinger EC, Sarr D (2011) A power analysis for multivariate tests of temporal trend in species composition. Ecology 92(10):1879-1886

Jackson ST, Sax DF (2010) Balancing biodiversity in a changing environment: extinction debt, immigration credit and species turnover. Trends Ecol Evol 25(3):153-160

Johansson T, Gibb H, Hjältén J, Pettersson RB, Hilszczański J, Alinvi O, Ball JP, Danell K (2007) The effects of substrate manipulations and forest management on predators of saproxylic beetles. For Ecol Manag 242(2):518529

Johansson T, Andersson J, Hjältén J, Dynesius M, Ecke F (2011) Short-term responses of beetle assemblages to wildfire in a region with more than 100 years of fire suppression. Insect Conserv Divers 4(2):142-151

Johansson T, Hjältén J, de Jong J, von Stedingk H (2013) Environmental considerations from legislation and certification in managed forest stands: a review of their importance for biodiversity. For Ecol Manag 303:98-112

Jonsell M, Weslien J, Ehnström B (1998) Substrate requirements of red-listed saproxylic invertebrates in Sweden. Biodivers Conserv 7(6):749-764

Koch K (1989a) Die Käfer Mitteleuropas. Ökologie, Band 1. Goecke \& Evers, Krefeld

Koch K (1989b) Die Käfer Mitteleuropas. Ökologie, Band 2. Goecke \& Evers, Krefeld

Koch K (1992) Die Käfer Mitteleuropas. Ökologie, Band 3. Goecke \& Evers, Krefeld

Koivula M, Vanha-Majamaa I (2020) Experimental evidence on biodiversity impacts of variable retention forestry, prescribed burning, and deadwood manipulation in Fennoscandia. Ecol Process 9:11
Kouki J, Hyvärinen E, Lappalainen H, Martikainen P, Similä M (2012) Landscape context affects the success of habitat restoration: large-scale colonization patterns of saproxylic and fire-associated species in boreal forests. Divers Distrib 18(4):348-355

Lekander B, Bejer-Petersen B, Kangas E, Bakke A (1977) The distribution of bark beetles in the Nordic countries. Acta Entomologica Fennica 32:1-36

Liljeblad J (2020). Dyntaxa. Svensk taxonomisk databas. Version 1.2. SLU Artdatabanken. Checklist dataset https://doi.org/10.15468/j43wfc accessed via GBIF.org on 2020-08-02.

Ljungberg H (2005) Artfakta: Quedius lundbergi. Swedish University of Agricultural Sciences, Artdatabanken

Löbl I, Mattila J (2010) Euplectus lapponicus (Coleoptera: Staphylinidae: Pselaphinae), a new species from boreal Finnland. Entomologica Fennica 21: 181-186

Martikainen P, Siitonen J, Punttila P, Kaila L, Rauh J (2000) Species richness of Coleoptera in mature managed and old-growth boreal forests in southern Finland. Biol Conserv 94(2):199-209

McMinn JW, Crossley DA (1996) Biodiversity and coarse woody debris in southern forests: DIANE Publishing

Niklasson M, Granström A (2000) Numbers and sizes of fires: long-term spatially explicit fire history in a Swedish boreal landscape. Ecology 81(6): 1484-1499

Nilsson S, Niklasson M, Hedin J, Aronsson G, Gutowski J, Linder P, Ljungberg H, Mikusiński G, Ranius T (2002) Densities of large living and dead trees in old-growth temperate and boreal forests. For Ecol Manag 161:189-204

Oksanen J, Blanchet F, Kindt R, Legendre P, Minchin P, O'Hara R, Simpson G, Solymos P, Stevens M, Wagner H (2015) Vegan: community ecology. R package version 2:2-1

Östlund L, Zackrisson O, Axelsson A-L (1997) The history and transformation of a Scandinavian boreal forest landscape since the 19th century. Can J For Res 27(8):1198-1206

Paillet Y, Bergén L, Hjältén J, Ódor P, Avon C, Bernhardt-Römermann M, Bijlsma RJ, De Bruyn LUC, Fuhr M, Grandin ULF, Kanka R, Lundin L, Luque S, Magura T, Matesanz S, Mészáros I, Sebastiá MT, Schmidt W, Standovár T, Tóthmérész B, Uotila A, Valladares F, Vellak KAl, Virtanen R (2010) Biodiversity differences between managed and unmanaged forests: meta-analysis of species richness in Europe. Conserv Biol 24(1):101-112

Penttilä R, Siitonen J, Kuusinen M (2004) Polypore diversity in managed and oldgrowth boreal Picea abies forests in southern Finland. Biol Conserv 117(3): 271-283

Ripley B, Venables B, Bates DM, Hornik K, Gebhardt A, Firth D, Ripley MB (2013) Package 'mass'. CRAN Repos. Httpcran R-Proj. OrgwebpackagesMASSMASS Pdf

Saint-Germain M, Drapeau P, Hébert C (2004) Comparison of Coleoptera assemblages from a recently burned and unburned black spruce forests of northeastern North America. Biol Conserv 118(5):583-592

Saint-Germain M, Drapeau P, Buddle CM (2008) Persistence of pyrophilous insects in fire-driven boreal forests: population dynamics in burned and unburned habitats. Divers Distrib 14(4):713-720

Sánchez-Bayo F, Wyckhuys KAG (2019) Worldwide decline of the entomofauna: a review of its drivers. Biol Conserv 232:8-27

Siitonen J (2001) Forest management, coarse woody debris and saproxylic organisms: Fennoscandian boreal forests as an example. Ecol Bull 49:11-41

SMHI. Available at: https://www.smhi.se/klimatdata/meteorologi/ladda-nermeteorologiska-observationer/\#param=airtemperaturelnstant,stations=all [2018-12-14]

Speight MC (1989) Saproxylic invertebrates and their conservation. Council of Europe

Stenbacka F, Hjältén J, Hilszczański J, Dynesius M (2010) Saproxylic and nonsaproxylic beetle assemblages in boreal spruce forests of different age and forestry intensity. Ecol Appl 20(8):2310-2321

Stokland JN (2001) The coarse woody debris profile: an archive of recent forest history and an important biodiversity indicator. Ecol Bull 49:71-83

Stokland JN, Siitonen J, Jonsson BG (2012) Biodiversity in Dead Wood. (Ecology, Biodiversity and Conservation). Cambridge: Cambridge University Press. Available from: https://www.cambridge.org/core/books/biodiversity-in-deadwood/32EA8DA79A503B95795384FFA5BC993D

Svensson J, Andersson J, Sandström P, Mikusiński G, Jonsson BG (2019) Landscape trajectory of natural boreal forest loss as an impediment to green infrastructure. Conserv Biol 33(1):152-163 
Toivanen T, Kotiaho JS (2007) Mimicking natural disturbances of boreal forests: the effects of controlled burning and creating dead wood on beetle diversity. Biodivers Conserv 16(11):3193-3211

Vahlström I (2019) Community structure of polyporous fungi after wildfire in boreal forest. Diss. Umeå: Swedich University of Agricultural Sciences Vanha-Majamaa I, Lilja S, Ryömä R, Kotiaho JS, Laaka-Lindberg S, Lindberg H, Puttonen P, Tamminen P, Toivanen T, Kuuluvainen T (2007) Rehabilitating boreal forest structure and species composition in Finland through logging, dead wood creation and fire: the EVO experiment. For Ecol Manag 250(1):77-88

Wallenius TH, Lilja S, Kuuluvainen T (2007) Fire history and tree species composition in managed Picea abies stands in southern Finland: implications for restoration. For Ecol Manag 250(1):89-95

Westling A (2015) Rödlistade arter i Sverige 2015. ArtDatabanken, SLU, Uppsala

White EP (2004) Two-phase species-time relationships in north American land birds. Ecol Lett 7(4):329-336

Wikars L-O (1997) Effects of forest fire and the ecology of fire-adapted insects: Acta Universitatis Upsaliensis

Wikars L-O (2001) The wood-decaying fungus Daldinia loculata (Xylariaceae) as an indicator of fire-dependent insects. Ecol Bull 49:263-268

Wikars L-O (2002) Dependence on fire in wood-living insects: an experiment with burned and unburned spruce and birch logs. J Insect Conserv 6(1):1-12

Wikars L-O (2006) Åtgärdprogram för bevarande av brandinsekter i boreal skog (report number:5610): Swedish Environmental Protection Agency

Wikars L-O, Sahlin E, Ranius T (2005) A comparison of three methods to estimate species richness of saproxylic beetles (Coleoptera) in logs and high stumps of Norway spruce. The Canadian Entomologist 137(3):304-324

Zackrisson O (1977) Influence of forest fires on the north Swedish boreal forest. Oikos 29(1):22-32

\section{Publisher's Note}

Springer Nature remains neutral with regard to jurisdictional claims in published maps and institutional affiliations.

\section{Submit your manuscript to a SpringerOpen ${ }^{\circ}$ journal and benefit from:}

- Convenient online submission

- Rigorous peer review

- Open access: articles freely available online

High visibility within the field

- Retaining the copyright to your article

Submit your next manuscript at $\boldsymbol{\nabla}$ springeropen.com 